\title{
Satellite-based detection of volcanic sulphur dioxide from recent eruptions in Central and South America
}

\author{
D. Loyola ${ }^{1}$, J. van Geffen ${ }^{2}$, P. Valks ${ }^{1}$, T. Erbertseder ${ }^{3}$, M. Van Roozendael ${ }^{2}$, W. Thomas ${ }^{4}$, W. Zimmer ${ }^{1}$, and \\ K. Wißkirchen ${ }^{3}$ \\ ${ }^{1}$ German Aerospace Center (DLR), Remote Sensing Technology Institute (IMF), 82234 Wessling, Germany \\ ${ }^{2}$ Belgian Institute for Space Aeronomy, Av. Circulaire 3, 1180 Brussels, Belgium \\ ${ }^{3}$ German Aerospace Center (DLR), German Remote Sensing Data Center (DFD), 82234 Wessling, Germany \\ ${ }^{4}$ Deutscher Wetterdienst (DWD), P.O. Box 1004 65, 63004 Offenbach, Germany
}

Received: 15 June 2007 - Revised: 12 October 2007 - Accepted: 13 October 2007 - Published: 2 January 2008

\begin{abstract}
Volcanic eruptions can emit large amounts of rock fragments and fine particles (ash) into the atmosphere, as well as several gases, including sulphur dioxide $\left(\mathrm{SO}_{2}\right)$. These ejecta and emissions are a major natural hazard, not only to the local population, but also to the infrastructure in the vicinity of volcanoes and to aviation. Here, we describe a methodology to retrieve quantitative information about volcanic $\mathrm{SO}_{2}$ plumes from satellite-borne measurements in the UV/Visible spectral range. The combination of a satellitebased $\mathrm{SO}_{2}$ detection scheme and a state-of-the-art 3D trajectory model enables us to confirm the volcanic origin of trace gas signals and to estimate the plume height and the effective emission height. This is demonstrated by case-studies for four selected volcanic eruptions in South and Central America, using the GOME, SCIAMACHY and GOME-2 instruments.
\end{abstract}

\section{Introduction}

Volcanic eruptions and outgassing are the most important natural sources of $\mathrm{SO}_{2}$ (Graf et al., 1997). Most volcanic $\mathrm{SO}_{2}$ emissions and aerosols remain in the troposphere. There, the lifetime of $\mathrm{SO}_{2}$ depends strongly on meteorological conditions but it is typically in the order of a few days. In the troposphere, the major sink of $\mathrm{SO}_{2}$ is its transformation into sulphate aerosol and sulphuric acid, the latter being responsible for the "acid rain" phenomenon. Since $\mathrm{SO}_{2}$ is also toxic it has to be considered a possible hazard to human health (e.g. EPA, 2007).

Correspondence to: D. Loyola

(diego.loyola@dlr.de)
Severe volcanic eruptions, such as those of El Chichon (1982) and Pinatubo (1991), can bring a considerable amount of sulphur dioxide and particles into the stratosphere. Here, the $\mathrm{SO}_{2}$ is mainly transformed into sulphuric droplets (aerosols). These aerosol droplets may persist for weeks in the stratosphere and may be transported on intercontinental scales (Read et al., 1993). Sulphate aerosol has a cooling effect on the atmosphere and leads to enhanced rates of ozone loss in the lower stratosphere, as it was observed after the Pinatubo eruption (Self et al., 1996).

Satellite remote sensing of volcanic $\mathrm{SO}_{2}$ provides a unique global and systematic way of detecting and tracking volcanic gas plumes and their evolution in near-real time, thus delivering additional information to authorities to take appropriate actions. The new generation of atmospheric remote sensing sensors allows the accurate detection of volcanic $\mathrm{SO}_{2}$ plumes and ash clouds. Especially the latter are also a hazard to aviation: the ash can limit the view of aircraft pilots and it can melt inside the engines, as a result of which the engines may fail. Since $\mathrm{SO}_{2}$ is also dissolved in water droplets and forms corrosive sulphuric acid, it can create sulphate deposits in the engines (van Geffen et al., 2007).

The main focus of this paper is the retrieval of $\mathrm{SO}_{2}$ using satellite measurements in the UV spectral range from the Global Ozone Monitoring Experiment (GOME) (Burrows et al., 1999) on-board ERS-2 and the Scanning Imaging Absorption Spectrometer for Atmospheric CHartographY (SCIAMACHY) (Bovensmann et al., 1998; Gottwald et al., 2006) on-board ENVISAT. We focus on major eruptions of four volcanoes in South and Central America during the last decade. Finally, the perspectives for global $\mathrm{SO}_{2}$ monitoring using GOME-2 data on-board MetOp and the issues related to the near-real time retrieval and delivery of $\mathrm{SO}_{2}$ data are addressed. 

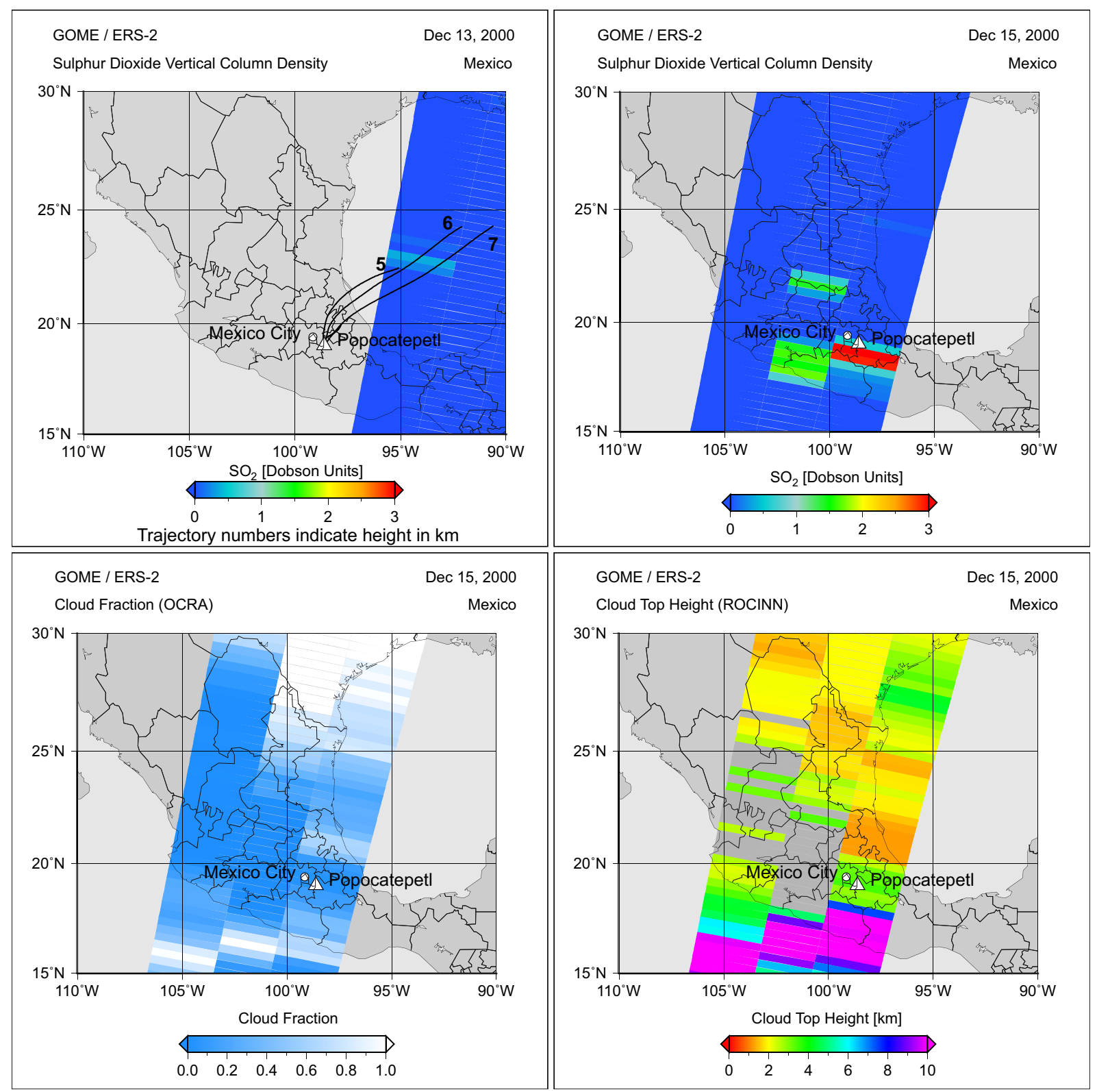

Fig. 1. $\mathrm{SO}_{2}$ vertical column densities as retrieved from GOME for 13 December 2000 (top-left). Representing a coherent ensemble of matching forward trajectories, three trajectories are plotted released at the Popocatepetl at altitudes from 5 to $7 \mathrm{~km}$ and durations of $24 \mathrm{~h}$. The other panels show $\mathrm{SO}_{2}$ vertical column densities, cloud fraction and cloud top height on 15 December 2000.

\section{$2 \mathrm{SO}_{2}$ column retrieval}

The $\mathrm{SO}_{2}$ column along slant absorption paths is retrieved from the UV backscatter spectra by GOME and SCIAMACHY, applying the well-established Differential Optical Absorption Spectroscopy (DOAS) approach (Platt, 1994). The non-linear least square fit is performed in the 315$326 \mathrm{~nm}$ wavelength range and provides the $\mathrm{SO}_{2}$ slant column (Eisinger et al., 1998). Absorption cross-sections of sulphur dioxide, ozone, nitrogen dioxide and a correction for the Ring effect (rotational Raman scattering) are fitted simultaneously. Furthermore, a $\mathrm{SO}_{2}$ background correction is applied to account for systematic artefacts introduced by the interference between ozone and $\mathrm{SO}_{2}$ in the given spectral window.

In the next step, the $\mathrm{SO}_{2}$ slant columns are converted to geometrically independent vertical column amounts through division mass factors (AMF). The AMFs are calculated with the radiative transfer model LIDORT (LInearized Discrete Ordinate Radiative Transfer model) (Spurr et al., 2001) and depend on the viewing geometry, the reflection properties of the underlying surface, the $\mathrm{SO}_{2}$ plume height, and the pres- 


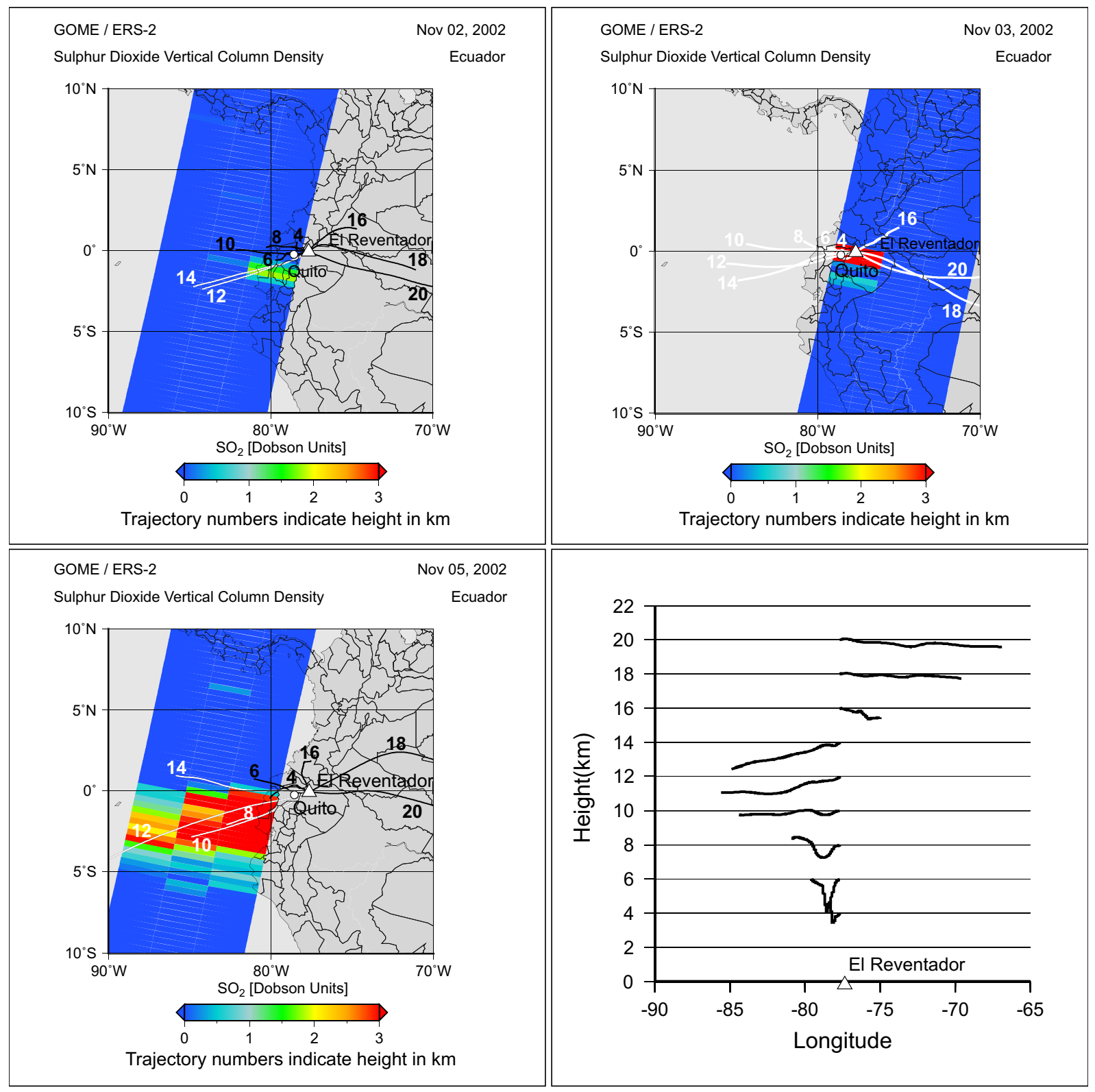

Fig. 2. $\mathrm{SO}_{2}$ vertical column densities of the eruption of El Reventador, Ecuador for 2, 3 and 5 November 2002, as measured by GOME. Trajectories were released from $4 \mathrm{~km}$ to $20 \mathrm{~km}$ in steps of $2 \mathrm{~km}$ using durations of $24 \mathrm{~h}$. The trajectories matching the plume are coloured in white. Bottom-right: Longitudinal crosssection of the forward trajectories released for the El Reventador eruption at 3 November 2002. Trajectories were released at 06:00 UTC from 4 to $20 \mathrm{~km}$ above sea level in steps of $2 \mathrm{~km}$ using durations of $24 \mathrm{~h}$. The vertical wind shear between $14 \mathrm{~km}$ and $16 \mathrm{~km}$ can be well recognized.

ence and optical properties of clouds and aerosols (Thomas et al., 2005).

\section{Trajectory analysis}

In order to attribute increased $\mathrm{SO}_{2}$ values as found in satellite-based observations to a particular volcano or an active volcanic region, we apply the trajectory matching tech- nique (Thomas et al., 2005). By means of calculating ensembles of backward trajectories starting from enhanced $\mathrm{SO}_{2}$ column observations, the volcanic origin of such $\mathrm{SO}_{2}$ plumes can be identified or rejected. In the latter case the emission can be attributed e.g., to anthropogenic processes or other natural sources. The quantitative retrieval of $\mathrm{SO}_{2}$ column densities strongly depends on the $\mathrm{SO}_{2}$ plume height, i.e. the sulphur dioxide profile. We determine the unknown plume height and the emission height of $\mathrm{SO}_{2}$ at a volcano using the 


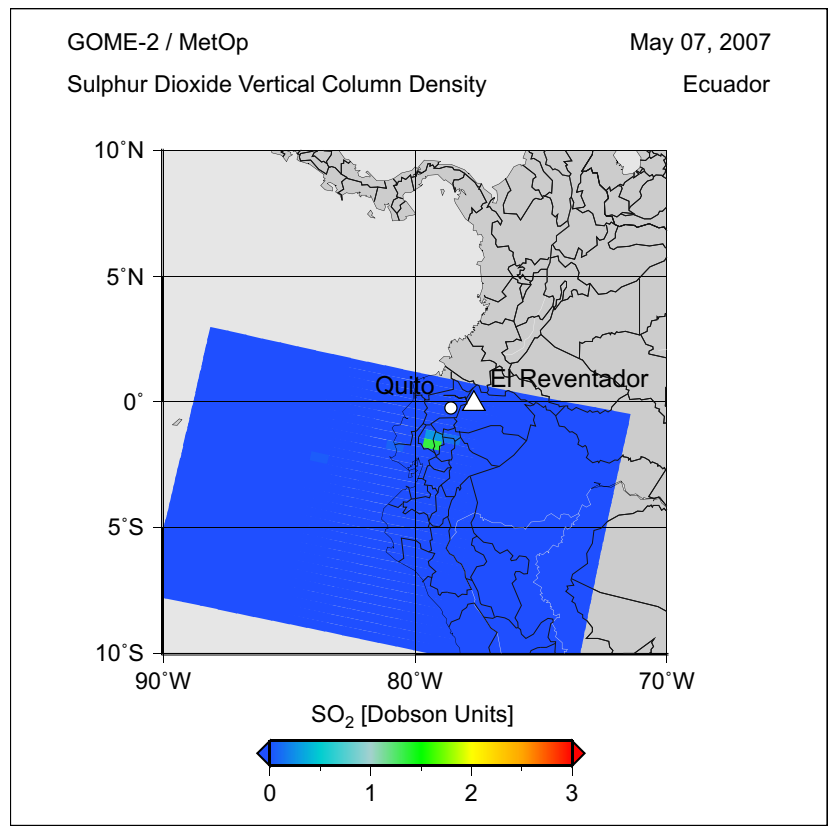

Fig. 3. $\mathrm{SO}_{2}$ vertical column densities derived from GOME-2 for the eruption of El Reventador/Ecuador for 7 May 2007. Backward trajectories calculated for this case indicate an emission height of $6 \mathrm{~km}$.

3-D trajectory model FLEXTRA (Stohl et al., 1999). This model is driven by meteorological analyses of the European Centre for Medium Range Weather Forecast (ECMWF). Ensembles of backward trajectories were released at different pressure levels from $2 \mathrm{~km}$ to $20 \mathrm{~km}$ at the geolocation of satellite-based observations with elevated $\mathrm{SO}_{2}$ columns. This allows confirming the volcanic origin of the $\mathrm{SO}_{2}$, determining the effective emission height over the volcano and revealing the spatial and temporal evolution of the $\mathrm{SO}_{2}$ plume. In order to reconfirm an estimated volcanic source, ensembles of 3-D forward trajectories were released at volcanoes (see Sect. 4) at different levels ranging from $2 \mathrm{~km}$ to $20 \mathrm{~km}$ above mean sea level (AMSL). By matching the parcel trajectories with the first guess satellite-based $\mathrm{SO}_{2}$ retrievals the height of the $\mathrm{SO}_{2}$ plume is determined. The accuracy of the combined retrieval and trajectory matching approach was evaluated in Thomas et al. (2005) using ground-based measurements of $\mathrm{SO}_{2}$ and aerosols.

\section{Case studies}

This section presents the $\mathrm{SO}_{2}$ and trajectory analysis for selected eruptions of four volcanoes in South and Central America. We used observations from the GOME and SCIAMACHY sensors, as well as data from the recently launched GOME-2 instrument. Important differences between the instruments are the spatial resolution and the temporal coverage. The spatial resolution for GOME is $320 \times 40 \mathrm{~km}^{2}$, pro- viding global coverage within 3 days, SCIAMACHY has a spatial resolution of $60 \times 30 \mathrm{~km}^{2}$ and global coverage is reached within 6 days only. The new GOME-2 instrument offers nearly global coverage within one day at a spatial resolution of about $80 \times 40 \mathrm{~km}^{2}$.

\subsection{Popocatepetl, 12-15 December 2000}

Popocatepetl $\left(19^{\circ} 1^{\prime} \mathrm{N}, 98^{\circ} 37^{\prime} \mathrm{W}\right)$, located $70 \mathrm{~km}$ south-east from Mexico City, erupted from 12-15 December 2000. Popocatepetl is one of the most active volcanoes in Mexico. The $\mathrm{SO}_{2}$ vertical column densities as retrieved from GOME for 13 December 2000 are shown in Fig. 1. The enhanced $\mathrm{SO}_{2}$ values over the Gulf of Mexico were the first signal detected for this eruptive period and hence they were used to determine the origin of the $\mathrm{SO}_{2}$ and the effective emission height. The trajectory analysis revealed an effective emission height at the Popocatepetl between $5 \mathrm{~km}$ and $7 \mathrm{~km}$, which is around its summit height of $5462 \mathrm{~m}$. The three trajectories overlaid in Fig. 1 indicate the main path of the $\mathrm{SO}_{2}$ plume and are a subset of a coherent ensemble of matching forward trajectories (not shown here). They were released at 00:00 UTC at the geolocation of Popocatepetl and represent a travel time of $24 \mathrm{~h}$ at altitudes from $5 \mathrm{~km}$ and $7 \mathrm{~km}$. The retrieved $\mathrm{SO}_{2}$ vertical column densities, the cloud fraction and the cloud top height for 15 December 2000 are also depicted in Fig. 1. The low cloud fraction above the volcano provided good observation conditions. On this day, maximum $\mathrm{SO}_{2}$ column densities of $\sim 7$ Dobson Units were detected with GOME southwards from the volcano $\left(1 \mathrm{DU}=2.69 \times 10^{16} \mathrm{molec} / \mathrm{cm}^{2}\right)$.

\subsection{El Reventador, 2-5 November 2002 and 7 May 2007}

El Reventador $\left(0^{\circ} 4^{\prime} \mathrm{S}, 77^{\circ} 39^{\prime} \mathrm{W}\right)$ is located $90 \mathrm{~km}$ north-east from Quito/Ecuador and erupted from 2-5 November 2002. Due to a strong wind shear between $14 \mathrm{~km}$ and $16 \mathrm{~km}$ altitude, the plume split in two, one part moving east and reaching $20 \mathrm{~km}$ height, and the other part moving south-west and reaching $14 \mathrm{~km}$ height. The GOME-based $\mathrm{SO}_{2}$ vertical column densities of this eruptive period are presented in Fig. 2 for 2, 3 and 5 November 2002. The trajectory analysis revealed an effective emission height at the Reventador between $4 \mathrm{~km}$ and $14 \mathrm{~km}$ in south-westerly direction and between $14 \mathrm{~km}$ to $20 \mathrm{~km}$ in easterly direction. This is corroborated by airplane observations (VAAC Washington, 2002). The trajectories depicted in Fig. 2 confirm the observed transport of the $\mathrm{SO}_{2}$ plume. They were released at 15:00 UTC at the Reventador (06:00 UTC for 3 November 2002) and represent a travel time of $24 \mathrm{~h}$ at altitudes ranging from $4 \mathrm{~km}$ to $20 \mathrm{~km}$. Trajectories matching the plume are coloured in white while others are black. For 2 November 2002 the matching trajectories can be associated with heights between $12 \mathrm{~km}$ and $14 \mathrm{~km}$, respectively. At 3 November 2002 all released trajectories cover the $\mathrm{SO}_{2}$ plume and at 5 Novem- 

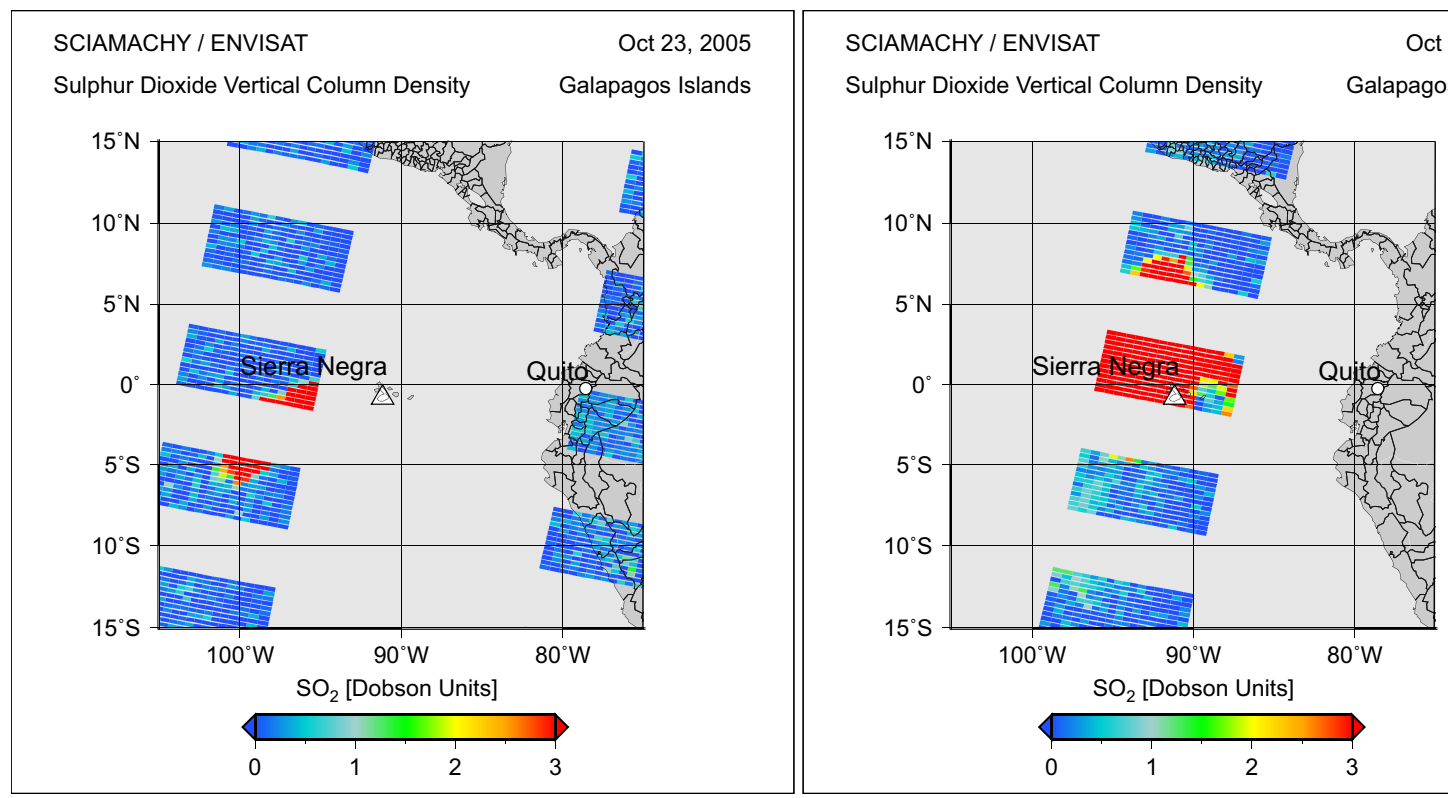

Fig. 4. $\mathrm{SO}_{2}$ vertical column densities retrieved from SCIAMACHY for the eruption of Sierra Negra on the Galapagos Island for 23 and 24 October 2005.

ber 2002 the trajectories from levels between $8 \mathrm{~km}$ to $14 \mathrm{~km}$ match the $\mathrm{SO}_{2}$ plume. Maximum $\mathrm{SO}_{2}$ columns of $\sim 10 \mathrm{DU}$ were measured with GOME on 3 November 2002, close to the volcano.

More recent eruptions of the El Reventador took place during March and May 2007 and were observed by GOME-2. Backward trajectories calculated for the eruption on 7 May 2007 revealed an emission height of $6 \mathrm{~km}$. Figure 3 shows the $\mathrm{SO}_{2}$ vertical columns derived from preliminary GOME2 data for 7 May 2007. A relatively small $\mathrm{SO}_{2}$ amount of $\sim 1.7 \mathrm{DU}$ was measured for the plume south-westerly of the volcano. Figure 3 shows also the smaller GOME-2 groundpixels and the larger swath-width of the GOME-2 instrument compared to GOME.

\subsection{Sierra Negra, 23-24 October 2005}

The Sierra Negra volcano $\left(0^{\circ} 49^{\prime} \mathrm{S}, 91^{\circ} 10^{\prime} \mathrm{W}\right)$, located on the Isla Isabela of the Galapagos archipelago (Ecuador), erupted on 23 October 2005. The eruption produced a large amount of volcanic smog (vog), which is typically a mixture of $\mathrm{SO}_{2}$, oxygen, water, and aerosols. The vog spread over several hundred square-kilometres of the Pacific Ocean. Figure 4 shows the $\mathrm{SO}_{2}$ vertical column densities for 23 and 24 October 2005 retrieved from SCIAMACHY observations. Backward trajectories calculated for 23 October 2005 indicate a plume height of $12 \mathrm{~km}$. While the moving direction of the plume on 23 October 2007 was to west-southwest direction, we could not find a preferred direction for the 24 October 2007. We therefore found elevated $\mathrm{SO}_{2}$ values in nearly the whole region around Sierra Negra. On 24 October 2007, very large $\mathrm{SO}_{2}$ column densities of more than 60 Dobson Units were detected with SCIAMACHY, close to the volcano.

\section{Conclusions}

We have shown the unique possibilities of satellite remote sensing in detecting and tracking volcanic $\mathrm{SO}_{2}$ plumes. The GOME (ERS-2), SCIAMACHY (ENVISAT) and GOME-2 (MetOp) satellite instruments allow retrieving atmospheric $\mathrm{SO}_{2}$ column densities on a global scale and in near-real time. By combining the satellite-based $\mathrm{SO}_{2}$ retrieval with state-ofart 3-D trajectory models, the volcanic origin can be confirmed, and the plume and effective emission heights can be estimated. The maximum $\mathrm{SO}_{2}$ column densities of the four eruptions analysed in this study, range from $\sim 1.7$ Dobson Units for the El Reventador eruption in May 2007, to more than 60 DU for the Sierra Negra eruption in October 2005.

Volcanic eruptions are a major hazard to aviation, and the only safe solution for aircrafts is to avoid flying through such volcanic clouds. The Volcanic Ash Advisory Centres (VAACs) have been set up by the International Civil Aviation Organisation (ICAO) to gather information on volcanic activity and to issue alerts on the possible danger of volcanic eruptions to aviation. To assist the VAACs in their task, the Support to Aviation Control Service (SACS) of the PROMOTE project intends to deliver in near-real-time $\mathrm{SO}_{2}$ data and, in the event of high $\mathrm{SO}_{2}$ concentrations, notifications by email to the VAACs and other interested parties (van Geffen et al., 2007). The $\mathrm{SO}_{2}$ data of SACS can be accessed 
via http://sacs.aeronomie.be/ or via the PROMOTE website http://www.gse-promote.org/ under "Special Services".

Acknowledgements. GOME and SCIAMACHY level 1 data were provided by ESA, GOME-2 level 1 data was provided by EUMETSAT. We thank A. Stohl for providing the FLEXTRA model and ECMWF for the access to the meteorological analyses. We are grateful to the two referees for their valuable comments.

Edited by: P. Fabian

Reviewed by: two anonymous referees

\section{References}

Bovensmann, H., Burrows, J. P., Buchwitz, M., Frerick, J., Noel, S., Rozanov, V. V, Chance, K. V., and Goede, A. P. H.: SCIAMACHY: Mission Objectives and Measurement Modes, J. Atmos. Sci., 56, 127-150, 1999.

Burrows, J. P., Weber, M., Buchwitz, M., Rozanov, V., LadstaetterWeissenmayer, A., Richter, A., de Beek, R., Hoogen, R., Bramstedt, K., Eichmann, K.-U., Eisinger, M., and Perner, D.: The Global Ozone Monitoring Experiment (GOME): Mission concept and first scientific results, J. Atmos. Sci., 56, 151-175, 1999.

Eisinger, M. and Burrows, J. P.: Tropospheric Sulphur Dioxide observed by the ERS-2 GOME Instrument, Geophys. Res. Lett., 25, 4177-4180, 1998.

EPA (Environmental Protection Agency of the United States): Health and Environmental Impacts of SO2, http://www.epa.gov/ air/urbanair/so2/index.html, 2007

van Geffen, J., Van Roozendael, M. , Di Nicolantonio, W., Tampellini, L., Valks, P., Erbertseder, T., and van der A, R., Monitoring of volcanic activity from satellite as part of GSE PROMOTE, Proceedings of the ENVISAT Symposium, 23-27 April 2007, Montreux, Switzerland, ESA publication SP-636, 2007.

Gottwald, M., Bovensmann, H., Lichtenberg, G., Noel, S., von Bargen, A., Slijkhuis, S., Piters, A., Hoogeveen, R., von Savigny, C., Buchwitz, M., Kokhanovsky, A., Richter, A., Rozanov, A., Holzer-Popp, T., Bramstedt, K., Lambert, J.-C., Skupin, J., Wittrock, F., Schrijver, H., and Burrows, J. P.: SCIAMACHY, Monitoring the Changing Earth's Atmosphere, published by DLR, 2006.
Graf, H.-F., Feichter, J., and Langmann, B.: Volcanic sulfur emissions: Estimates of source strength and its contribution to the global sulfate distribution, J. Geophys. Res., 102, 10 727-10 738, 1997.

Platt, U.: Differential optical absorption spectroscopy (DOAS), Air Monitoring by Spectroscopic Techniques, edited by: Siegrist, M., Chemical Analysis Series, 127, 1994.

Read, W. G., Froidevaux, L., and Waters, J. W.: Microwave Limb Sounder (MLS) measurements of $\mathrm{SO}_{2}$ from Mt. Pinatubo volcano, Geophys. Res. Lett. 20, 1299-1302, 1993.

Self, S., Zhao, J.-X., Holasek, R. E., Torres, R. C., and King, A. J.: The atmospheric impact of the 1991 Mount Pinatubo eruption, in: Fire and Mud: Eruptions and lahars of Mount Pinatubo, edited by: Newhall, C. G. and Punongbayan, R. S., Philippines Philippine Institute of Volcanology and Seismology, Quezon City, and University of Washington Press, Seattle and London, 1996.

Spurr, R. J. D., Kurosu T. P., and Chance K. V.: A linearized discrete ordinate radiative transfer model for atmospheric remote sensing retrieval, J. Quant. Spec. Radiat. Transfer, 68, 689-735, 2001.

Stohl, A., Haimberger, L., Scheele, M., and Wernli, H.: An intercomparison of results from three trajectory models, Meteorol. Appl., 8, 127-135, 1999.

Thomas, W., Erbertseder, T., Ruppert, T., van Roozendael, M., Verdebout, J., Meleti, C., Balis, D., and Zerefos, C.: On the retrieval of Volcanic Sulfur Dioxide Emissions from GOME backscatter measurements, J. Atmos. Chem., 50, 295-320, doi:10.1007/s10874-005-5079-5, 2005.

VAAC Washington (Volcanic Ash Advisory Center) VOLCANIC ASH ADVISORY FVXX21 KWBC 040000, issued: 002NOV04/0000Z, http://www.ssd.noaa.gov/VAAC/ARCH02/ REVE/2002K040000.html, 2002. 